\title{
Carboxylation of $\beta$-methylcrotonyl coenzyme $A$ by a purified enzyme from chicken liver
}

In an earlier study ${ }^{1,2}$ of leucine metabolism in crude heart extracts, data were obtained indicating that $\beta$-methylcrotonyl $\operatorname{CoA}$ is acted upon by enoyl hydrase (crotonase) and that the resulting $\beta$-hydroxyisovaleryl $\operatorname{CoA}$ is carboxylated enzymically in the presence of ATP to yield $\beta$-hydroxy- $\beta$-methylglutaryl CoA. This product is known ${ }^{3}$ to be attacked by a specific cleavage enzyme to furnish equimolar amounts of acetoacetate and acetyl COA. LYNEN AND KNAPPE ${ }^{4-6}$ have recently made the interesting discovery, however, that $\beta$-methylcrotonyl $\operatorname{CoA}$ is carboxylated directly in crotonase-free enzyme preparations from $M y$ cobacterium spp. $\beta$-Methylglutaconyl $\mathrm{CoA}$, the product of this carboxylation reaction, is hydrated to yield $\beta$-hydroxy- $\beta$-methylglutaryl CoA by the action of methylglutaconase, a specific hydrase present in microorganisms and in animal tissues?

During the past two years we have been engaged in the purification of the relatively unstable carboxylase from chicken liver in the hope that interfering enzymes could be removed and the nature of this reaction in animal tissues could be established with finality. With a roo-fold purified preparation of the carboxylase, a requirement for methylglutaconase in the overall conversion of $\beta$-methylcrotonyl $\mathrm{CoA}$ to acetoacetate has been established (Table I). Furthermore, by employing carboxylase and cleavage-enzyme preparations preincubated with $p$-chloromercuribenzoate to inhibit the residual crotonase, $\beta$-methylcrotonyl $\operatorname{CoA}$, rather than $\beta$ hydroxyisovaleryl CoA, has been identified as the true substrate for the chicken-liver carboxylase (Table II). The further unexpected finding has been made that $\beta$-methylvinylacetyl $\mathrm{CoA}$ also gives rise to acetoacetate in this carboxylase system in the absence of added crotonase. The absorption maximum characteristic of $\alpha, \beta$-unsaturated thiol esters $(\lambda=267 \mathrm{~m} \mu$ for $\beta$-methylcrotonyl CoA) does not appear when

TABLE I

REQUIREMENT FOR METHYLGLUTACONASE IN CONVERSION OF $\beta$-METHYLCROTONYL CoA to ACETOACETATE

\begin{tabular}{clll}
\hline Expt. & \multicolumn{1}{c}{ System } & $\begin{array}{c}\text { Enzyme absent } \\
\text { trom reaction mixture }\end{array}$ & $\begin{array}{c}\text { Acetoacetale formed } \\
\text { ( } \mu \text { mole) }\end{array}$ \\
\hline & Complete & None & 0.14 \\
I & No pig-heart fraction & None & 0.14 \\
2 & No chicken-liver fraction & Carboxylase & 0.00 \\
3 & No ox-liver fraction & Methylglutaconase & 0.02
\end{tabular}

\begin{abstract}
The complete reaction mixture contained $200 \mu$ moles $\mathrm{KHCO}_{3}, 5 \mu$ moles glutathione, $2.5 \mu$ moles ethylenediaminetetraacetic acid, $25 \mu$ moles $\mathrm{MgCl}_{2}, 2.5 \mu$ moles ATP, I.3 $\mu$ moles $\beta$-methylcrotonyl $\mathrm{CoA}$, IOO-fold purified $\mathrm{CO}_{\mathrm{g}}$-activating enzyme $(0.2 \mathrm{mg}$ protein), Ioo-fold purified carboxylase from chicken liver (1.2 mg protein), a pig-heart fraction (shown to be free of methylglutaconase) containing 0.2 units of $\beta$-hydroxy- $\beta$-methylglutaryl CoA cleavage enzyme, and an ox-liver fraction containing methylglutaconase and 0.2 unit of $\beta$-hydroxy- $\beta$-methylglutaryl cleavage enzyme, in a final vol. of $2.2 \mathrm{ml}$. After incubation for $\mathrm{I} h$ at $38^{\circ}$ under $\mathrm{N}_{2}$ the reaction mixtures were deproteinized with trichloroacetic acid and aliquots were taken for the estimation of acetoacetate

The quantity of cleavage enzyme in Expt. 4 was adequate for full activity in the assay system, as indicated in Expt. 2.
\end{abstract}

Abbreviations: CoA, coenzyme A; ATP, adenosine triphosphate. 
TABLE II

\begin{tabular}{lcc}
\multicolumn{2}{c}{ SUBSTRATES FOR THE CARBOXYLATION REACTION } \\
\hline \multirow{2}{*}{ Substrate } & \multicolumn{2}{c}{ Actoactate formed ( $\mu$ mole) } \\
\cline { 2 - 3 } & Crotonase added & Crotomase absent \\
\hline & & \\
$\beta$-hydroxyisovaleryl CoA & 0.13 & 0.01 \\
$\beta$-methylcrotonyl CoA & 0.07 & $0.1 \mathrm{I}$ \\
$\beta$-methylvinylacetyl CoA & 0.06 & 0.09
\end{tabular}

The complete reaction mixture contained $\mathrm{KHCO}_{3}$, glutathione, ethylenediaminetetraacetic acid, $\mathrm{MgCl}_{2}$ and ATP as shown in Table I, I.3 $\mu$ moles of the thiol ester indicated, 8o-fold purified $\mathrm{CO}_{2}$-activating enzyme (0.I mg protein), $\beta$-hydroxy- $\beta$-methylglutaryl $\mathrm{CoA}$ cleavage enzyme partially purified from ox liver $(0.3 \mathrm{mg}$ protein), roo-fold purified carboxylase from chicken liver ( $0.4 \mathrm{mg}$ protein), and crystalline crotonase $(0.04 \mathrm{mg}$ protein) where indicated, in a final vol. of I.5 ml. The carboxylase and cleavage-enzyme preparations were preincubated with $p$-chloromercuribenzoate $\left(\mathrm{IO}^{-3} \mathrm{M}\right)$ for $15 \mathrm{~min}$ at $0^{\circ}$ to inactivate the crotonase present. Incubation. I h at $38^{\circ}$.

$\beta$-methylvinylacetyl CoA is incubated with the carboxylase alone. These observations suggest that, in the absence of crotonase, $\beta$-methylvinylacetyl CoA is either carboxylated directly or is transformed into $\beta$-methylcrotonyl CoA by the action of an isomerase ${ }^{10}$ in the reaction mixture, as indicated in the accompanying scheme. The conversion of $\beta$-methylvinylacetyl CoA to $\beta$-hydroxyisovaleryl $\mathrm{CoA}$ by the action of crotonase has been established previously ${ }^{11}$.

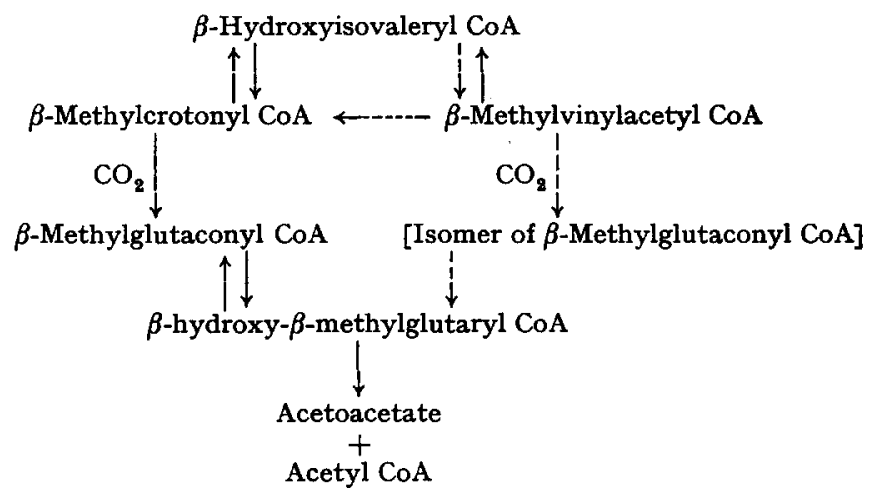

In view of the finding that $\beta$-methylcrotonyl $\operatorname{CoA}$ is carboxylated in the absence of crotonase in liver preparations, as in preparations of Mycobacterium spp. ${ }^{4-6}$, attempts are in progress to determine whether methylglutaconase plays any role in the carboxylase system from pig heart.

This work was supported by a grant from the U.S. Public Health Service (Grant A-993).

Department of Biological Chemistry, Medical School, The University of Michigan, Ann Arbor, Mich. (U.S.A.)
Alice del Campillo-Campbell ${ }^{\star}$ Eugene E. DeKKeR * Minor J. CoON

\footnotetext{
* Predoctoral Fellow of the U.S. Public Health Service.

* * Postdoctoral Fellow of the Life Insurance Medical Research Fund.
} 
1 B. K. Bachhawat, W. G. Robinson and M. J. Coon, J. Am. Chem. Soc., 76 (i954) 3098.

2 B. K. Bachhawat, W. G. Robinson and M. J. Coon, J. Biol. Chem., 219 (I956) 539.

3 B. K. Bachinawa, W. G. Robinson and M. J. Coon, J. Biol. Chem., 2 I 6 (I955) 727.

- F. LYNEN, Symposia on Enzyme Chemistry, Japan, October, 1957, in the press.

$5 \mathrm{~J}$. KNAPPE, Doctoral Thesis, University of Munich, 1957.

- J. KNappe and F. Lynen, 4th Intern. Congr. Biochem., Abstr. Communs., Vienna, Sept., I958, 49.

7 H. Hilz, J. Knappe, E. Ringelmann and F. Lynen, Biochem. Z., 329 (1958) 476.

8 B. K. Bachhawat and M. J. Coon, J. Biol. Chem., 23 I (I958) 625.

P. G. Walker, Biochem. J., 58 (I954) 699.

10 H. A. BARKer, Bacterial Fermentations, CIBA Lectures in Microbial Biochemistry, John Wiley and Sons, New York, I957, p. 44.

11 J. F. Woessner, Jr., B. K. Bachhawat and M. J. Coon, J. Biol. Chem., 233 (1958) 520.

Received October 3 rd, $195^{8}$

\section{Soluble pyridine nucleotide nucleosidase from seminal vesicles}

Pyridine nucleotide nucleosidases present in animal tissues are generally regarded as being intimately bound to the cell structure. In order to extract these enzymes it was necessary in the past to apply procedures involving the use of organic solvents ${ }^{1,2}$. In this communication we wish to report on the properties of a pyridine nucleotide nucleosidase which occurs in the seminal vesicles and vesicular secretion of the bull. In the course of purification it was found that the enzyme occurred in a soluble form and that the preparation possessed marked TPNase activity which equalled or even exceeded DPNase activity.

The secretion from the seminal vesicles of young mature bulls (one and a half years old) was expressed manually. Both the residual vesicular tissue and secretion, if not immediately utilised, were stored at $-20^{\circ}$. In order to extract the enzyme from the seminal-vesicle tissue, one part of mince, prepared by passing the seminal-vesicle tissue twice through a meat mincer, was mixed with 3 vol. water and centrifuged at low speed. The aqueous extract was used for further purification and the precipitate was discarded. Both the aqueous extract from the seminal vesicles and the vesicular secretion showed DPNase as well as TPNase activity. DPNase values, in units/ml, ranged from 37 to 48 (equivalent to $148-\mathrm{r} 92$ in the mince) for the extract from vesicles, and from I2I to 263 for the secretion. TPNase activity in the aqueous extracts of vesicles was approximately 35 units (equivalent to I4O in the mince), and in the secretion it ranged from 75 to 335 . Nearly all of the enzymic activity was present in the soluble form. This could be shown by the fact that when the aqueous extract and the secretion, respectively, were centrifuged in a Spinco Model $L$ at $100,000 \times g$ for $30 \mathrm{~min}$, the resulting clear supernatant from the tissue extract retained $76 \%$ of the DPNase activity present before centrifugation, and in the centrifuged secretion all of the activity remained in the supernatant.

It is obvious that from the bull seminal-vesicle tissue and secretion it is practicable to purify pyridine nucleotide nucleosidase without tedious solubilising procedures which are known to affect the enzyme yield adversely. The main steps in the purification, which was carried out in the cold room, are shown in Table I. The values given in that table were obtained with the use of $299 \mathrm{ml}$ of vesicular secretion as starting material. The secretion was first brought with $0.1 M$ acetic acid to $\mathrm{pH}$ about 4.5 . After centrifuging in a refrigerated centrifuge at $5500 \mathrm{rev} . / \mathrm{min}$ for $10 \mathrm{~min}$, $290 \mathrm{ml}$ of clear, deep-red fluid were obtained. After neutralisation with I $M \mathrm{NH}_{4} \mathrm{OH}$, 